\title{
Patterns of Information Seeking in the Humanities
}

\section{Stephen E. Wiberley, Jr., and William G. Jones}

This paper describes how humanists in a small, interdisciplinary group seek information. The humanists confirm findings of previous research, although with significant variations. $\mathrm{Hu}$ manists ignore online databases and seldom consult reference librarians, but they do rely on archivists and special collections librarians. They limit use of formal bibliography to one or two sources and employ it intensively only when exploring new topics. Often they disregard bibliography and find information by going to the person or location that can supply it. The paper concludes with questions for future research and suggestions for library practice.

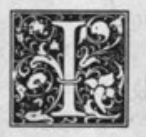

nformation seeking is a basic activity for all scholars. It is the aspect of scholarly work of most interest to academic librarians because academic libraries strive to develop collections, services, and organizational structures that will facilitate it. Yet information seeking is an activity about which we know less than we would like, especially for the humanities. A handful of recent studies have begun to dispel our ignorance of how humanists seek information, but we are still largely in the exploratory stage. ${ }^{1} \mathrm{~A}$ basic question these studies have asked is, "How do scholars identify what they will read?"

This question was very much on our minds when we began to participate as fellows in a year-long seminar in the humanities at the Institute for the Humanities (University of Illinois at Chicago). Our efforts were funded by the Council on Library Resources and devoted to addressing issues in strategic planning for libraries. Through our participation, we sought to learn more about how human- ists find and use information in their work and, from this, to develop questions for further research and to suggest library services that can help these scholars become more productive. From earlier studies of scholarly information seeking, principally surveys, we had learned that scholars rely, first, on the references in publications they read; second, on communications from colleagues; third, on formal bibliography (defined later); and fourth, on librarians. ${ }^{2}$ Because most of this earlier research antedates the recent, and rapidly expanding adoption of computers by humanists, we also set out to explore whether the increase in machine-readable information and in the use of computers by humanists had affected the way the fellows sought information. ${ }^{3}$

We proposed to take advantage of the small size of the seminar and the regular interaction among members to identify, through open-ended questions and unstructured discussions, issues and trends unreported by earlier surveys. Over the course of an academic year, we partici-

Stephen E. Wiberley, Jr., is Bibliographer for the Social Sciences and William G. Jones is Acting University Librarian, University of Illinois at Chicago, Chicago, Illinois 60680. The authors express their thanks to the Council on Library Resources for support of this work, to the 1987-88 fellows of the Institute for the Humanities at the University of Illinois at Chicago for their generous cooperation, to Mary Lynn Dietsche for her assistance in preparation of the manuscript, and to Robert W. Karrow, Jr., Beverly P. Lynch, and E. Paige Weston for their advice. 
pated in all the meetings of the seminar, including several group discussions about how members carried on their work. We also talked for two to four hours with each fellow about how he or she conducted research. Since what we heard was generally in line with previous findings, the small group we studied may, in most respects, be considered typical, and what we learned that has not been reported in earlier research may well be corroborated by future research. Our findings raise questions that deserve further exploration and point to areas of information seeking where scholars would benefit from consulting librarians more.

\section{THE SCHOLARS STUDIED}

It has been observed that of all scholars, humanists are most likely to work alone. ${ }^{4}$ The scholars in the seminar bear this out. All eleven were chosen for their year's fellowship based on projects that they conceived alone and were executing singlehandedly. In this respect they were very much following their past practices. Of more than 172 publications claimed by the fellows, only eight were coauthored; all the rest were written alone.

The members of the seminar came from seven departments: anthropology (two), English (three), history (two), history of art (one), philosophy (one), political science (one), and women's studies (one). One member was an assistant professor, four were associate professors, and six were full professors. In 1987, when the seminar began, they were, typically, at what might be termed mid-career: the median number of years since obtaining the doctorate was seventeen and the average was fifteen, with a range of five to twentyfour years.

On the whole, then, see table 1 , the seminar members were a mature group of scholars; almost all worked in traditional humanities disciplines. (Some historians see themselves as social scientists, but neither of the historians in the seminar did; nor did the professor from women's studies who was conducting historical research.) The three seminar members who came from fields usually classified in the social sciences-anthropology and politi- cal science-were conducting research that exemplified the recent trend for social scientists to return to the humanistic roots of their disciplines. ${ }^{5}$ All three were pursuing projects that entailed, to a significant extent, interpretation of documentary sources in a cultural context.

The fellows were very productive. It is difficult to make quantitative comparisons because data on publication rates are not available for humanities scholars. But comparison with academics from all disciplines suggests the fellows' distinctiveness. John Centra ${ }^{6}$ found that faculty from schools that put little emphasis on research typically publish fewer than two articles every five years. The average number of publications for faculty at schools that both did and did not emphasize research was fewer than three articles every five years. In contrast, for the five-year period prior to their appointment to the institute, the fellows averaged an equivalent of nearly eight articles.?

The above average rates of publication of the fellows suggest great expertise in their fields. They have largely gained their expertise by reading. While some reported they read rapidly and others said they read slowly, all revealed that they read frequently. They had developed a set of habits that continually brought them into contact with secondary sources (what other scholars write) that they had not seen before. Regarding primary sources (those that embody the topic under study), while two fellows concentrated on visual images and seven gathered evidence by talking with people, all read written primary sources. Here the contrasts among physical scientists, social scientists, and humanists seem strong. While scientists spend much of their time with collaborators working with laboratory equipment and social scientists spend much time with coinvestigators planning and executing field work, surveys, and data analysis, humanists spend most of their time alone, reading. ${ }^{8}$

Because academic libraries today are emphasizing the use of computers in information retrieval, we were interested in assessing the fellows' computer literacy. All reported using online public access 
TABLE 1

SUMMARY OF BACKGROUND DATA AND INFORMATION-SEEKING BEHAVIOR OF HUMANISTS STUDIED

\begin{tabular}{|c|c|c|c|c|c|c|c|c|c|}
\hline & & & & & Role of For & mal Bibliogr & aphy & & \\
\hline Rank & $\begin{array}{l}\text { Years } \\
\text { Since } \\
\text { Ph.D. }\end{array}$ & $\begin{array}{l}\text { Publication } \\
\text { Equivalent* } \\
\text { (1982-86) }\end{array}$ & $\begin{array}{l}\text { Coauthored } \\
\text { Publications } \\
\text { (Career) }\end{array}$ & $\begin{array}{c}\text { Computer } \\
\text { Uset }\end{array}$ & $\begin{array}{c}\text { Current } \\
\text { Awareness }\end{array}$ & $\begin{array}{c}\text { Essential } \\
\text { to Current } \\
\text { Project }\end{array}$ & None & $\begin{array}{c}\text { Use of } \\
\text { Geographic } \\
\text { Approach }\end{array}$ & $\begin{array}{l}\text { Use of } \\
\text { Genealogical } \\
\text { Approach }\end{array}$ \\
\hline Prof. & 24 & 8.7 & None & $\begin{array}{l}\text { E-mail } \\
\text { Word } \\
\text { Processing }\end{array}$ & $\mathrm{x}$ & $\mathrm{X}$ & & & \\
\hline Prof. & 21 & 2.0 & None & None & $\mathrm{X}$ & & & $\mathrm{X}$ & $\mathrm{x}$ \\
\hline Prof. & 19 & 10.3 & None & $\begin{array}{l}\text { Word } \\
\text { Processing }\end{array}$ & $\hat{x}$ & & & $\hat{x}$ & $x$ \\
\hline $\begin{array}{l}\text { Prof. } \\
\text { Prof. }\end{array}$ & $\begin{array}{l}18 \\
17\end{array}$ & $\begin{array}{l}7.0 \\
6.0\end{array}$ & $\begin{array}{c}\text { None } \\
1\end{array}$ & $\begin{array}{l}\text { None } \\
\text { Word } \\
\text { Processing }\end{array}$ & $\mathrm{x}$ & $X$ & & $\begin{array}{l}x \\
x\end{array}$ & $\mathrm{X}$ \\
\hline Prof. & 17 & 4.0 & 3 & None & & & $\mathrm{X}$ & $\mathrm{X}$ & 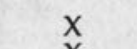 \\
\hline Assoc. Prof. & 12 & 10.0 & None & $\begin{array}{l}\text { Word } \\
\text { Processing }\end{array}$ & & $\mathrm{X}$ & & & $\mathrm{X}$ \\
\hline Assoc. Prof. & 12 & 5.0 & 2 & $\begin{array}{l}\text { E-Mail } \\
\text { Word }\end{array}$ & & $\mathrm{x}$ & & $x$ & $\mathrm{X}$ \\
\hline Assoc. Prof. & 11 & 16.0 & 2 & $\begin{array}{l}\text { Processing } \\
\text { Word } \\
\text { Processing }\end{array}$ & & & $\mathrm{x}$ & & \\
\hline $\begin{array}{l}\text { Assoc. Prof. } \\
\text { Asst. Prof. }\end{array}$ & $\begin{array}{l}9 \\
5\end{array}$ & $\begin{array}{r}10.0 \\
3.0\end{array}$ & $\begin{array}{l}\text { None } \\
\text { None }\end{array}$ & $\begin{array}{l}\text { None } \\
\text { Word } \\
\text { Processing }\end{array}$ & & & $\begin{array}{l}\mathrm{X} \\
\mathrm{x}\end{array}$ & & \\
\hline
\end{tabular}

* See no.7 in References and Notes.

tAll use online public access catalogs.

catalogs, although we had no way of assessing their proficiency. Four made no other use of computers. Seven used computers for word processing and two used electronic mail (E-mail). None had done an online search of a commercial database, although two had had searches done for them. Most of the fellows had begun to use computers recently, within the past two or three years-behavior much in line with national trends. ${ }^{9}$ But none reported that computers had transformed their work as has been the case for a few other humanists, many social scientists, and most scientists. ${ }^{10}$ Again, the contrasts among humanists, scientists, and social scientists are striking.

All of the fellows described in detail their use of information in their current work. Although several talked about use in past work, the description was usually briefer. We suspect (and in a few cases were told) that at sometime in their careers every fellow employed nearly all the approaches to information described in the following sections. But the account in this article of how the fellows identify what they read covers only their institute projects.

\section{USE OF LIBRARIANS AND FORMAL BIBLIOGRAPHY}

Given the individuality of humanists, it is not surprising that, instead of finding one or two patterns of use of libraries, librarians and formal bibliography, we found several, and the fellows combined these patterns in different ways. First, all seemed to rely partially or totally on library collections for their research, a pattern in line with other humanists who have been studied. ${ }^{11}$ Second, while fellows gave little or no evidence of consulting librarians in general reference departments, almost all who used archives or other special collections said they worked very closely with repository staff. Third, four fellows used one or two formal bibliographic tools regularly for current awareness, although not intensively, both to keep up with the literature and to advance their current research. Fourth, four reported that one or two formal bibliographic sources were essential for their current research. Fifth, four fellows recalled no regular or significant use of formal bibliography. Each of these patterns 
deserves elaboration.

All fellows reported using libraries without assistance to find books and journals they needed for research. Because most worked at more than one library, their success in this regard implies that they had some skill in using the varieties of public catalogs at American libraries. Although this skill may seem rudimentary to librarians, it is one of great power for the scholar. Key for the fellow is use of the public catalog to obtain conveniently, independently, and unobtrusively, almost all of the secondary literature cited in what he or she reads.

Self-reliance at finding books and journals may be one of the factors that makes it rare for fellows to consult librarians about matters relating to general collections. We were impressed by how many fellows told us they did not talk to librarians who worked in general reference departments. The fellows did not attribute their behavior to lack of confidence in reference librarians' abilities. (This finding contrasts with some, but not all, humanists who have been studied. ${ }^{12}$ ) Nor did the fellows ignore general reference librarians because they did not share the fellows' specializations. Instead, some fellows simply did not perceive a need to consult a reference librarian. Others reported that asking questions made them feel uncomfortable. One said he was hesitant to approach the reference desk because of his ignorance of many of the conventions of using the library. We speculate that because being knowledgeable is fundamental to the academic's sense of self, asking for information can be an unsettling experience. This may be particularly true in general reference departments where the materials used and their organization are comparatively wellknown and are often taught in graduate school, college, or, in some cases, high school.

In contrast, almost all fellows who used special collections, particularly of archives and manuscripts, reported that they depended heavily on the staff of these repositories. They begin work in the special collection by describing their projects to the curator, asking what materials and findings aids they should examine, and then pursuing the leads offered. In other words, when using a special collection, the scholars are not reluctant to ask questions. Perhaps this is so because scholars and librarians share expectations about use of a special collection. Unlike the general collection and reference department, the special collection has unique finding aids and materials; no one, including the scholars themselves, would expect them to have prior experience or training in the use of such sources.

Four fellows regularly consulted formal bibliography for current awareness. By formal bibliography we mean a work in which the bibliographic entries, their organization, and aids of access to them are central. Any expository writing that accompanies or explains the entries is secondary. In contrast, bibliography in scholarly publication supports and is subordinate to the argument, or the prose of that work. One fellow who has an interest in a region of Europe always reviewed the bibliographic listing in the quarterly newsletter of the American scholarly group that focuses on that region and another quarterly listing in the journal of the national association in her discipline. A second checked the sections for the two countries he studies in a quarterly listing of articles produced by a major American learned society. Another scanned a listing of journal articles that appeared in the quarterly journal of the national historical association that covers his country of interest. A fourth fellow kept up-to-date by consulting an annual bibliography, commercially published, that covered interdisciplinary scholarship about the era in which he specializes. Common characteristics of these cases are that the bibliographies (1) cover the scholar's long-standing interest, (2) appear serially, (3) are generally published by scholarly associations, and (4) treat secondary sources. Also, we found that there was no urgency or intensity in use: the fellows did not think that the quality of their current research projects would suffer if they did not use these bibliographies. Such listings were a convenient way of staying abreast of the literature and complemented finding references both by reading the literature itself 
and by talking with other specialists.

In four cases, formal bibliography provided information essential to the scholar's research. In one case, the topic was new to the scholar, dealt with recent history, and was covered both by a periodical index that gave access to primary sources and by a specialized bibliography that gave access to the primary and secondary literature. In two other cases, the formal bibliography used gave access to primary sources. For one fellow, a bibliography identified authors of unsigned articles in periodicals published during the period under study. For the other fellow, a bibliography assisted him in identifying all instances of a type of art by artists of a particular country. In a fourth case, the fellow was studying a new topic and needed an entrée to the secondary literature (her principal primary sources were interviews). She sent her research assistant to search the subject cata$\log$ of the library and the major periodical index in her discipline for citations to writings about the topic. In short, bibliography was most important for scholars when they were investigating unfamiliar primary sources or secondary literature about subjects unfamiliar to them.

Four scholars did not report use of formal bibliography. The most extreme case was a philosopher who claimed that, except for studying a relatively few canonical works, most of which he owned, he read little in the secondary literature that related to the philosophical problems he wrote about. A second fellow was working on a topic that centered on a single written primary source that was new to her. She supplemented this source with interviews. She kept up with secondary literature by scanning journals, reading publishers' advertisements, and going to conferences. A similar approach was followed by a literary critic and a film critic. They scanned numerous books and book reviews and frequently read unpublished manuscripts. Both already were familiar with the primary sources they were interpreting.

\section{DISCUSSION OF USE OF LIBRARIANS AND BIBLIOGRAPHY}

The fellows relied more heavily on for- mal bibliography and librarians for access to primary sources than they did for access to secondary sources. The scholars' greatest dependence on librarians and archivists was in special collections, the traditional home of primary sources. Of the four fellows who found formal bibliography essential, two sought primary sources, one both primary and secondary sources, and one secondary sources. Of the four scholars who most ignored bibliography and librarians, one did not use primary sources (the philosopher) and the other three were working with primary sources already familiar to them.

When fellows did use formal bibliography to find secondary sources, they generally did so with less urgency than those who searched bibliography for primary sources. The bibliographies used to find secondary sources were not the most sophisticated and comprehensive abstracting and indexing services available for the disciplines in question. That is, Abstracts in Anthropology, Historical Abstracts, America: History and Life, and the MLA Bibliography were not used, but much less complex and more limited sources were. Sue Stone reports a similar pattern among a small group of humanists at Sheffield, and Deirdre Stam found art historians used sophisticated services less than simpler ones. ${ }^{13}$ We wonder if this pattern exists because the bibliographies used are more focused or because they are easier to use. Stam's findings suggest ease of use may be most important. ${ }^{14}$ It is also noteworthy that bibliography used to locate secondary material usually came from the scholar's learned society (three of four cases). Use of such discipline-based bibliography relates closely to the scholars' identification of sources by reading the literature in their areas of specialization and consulting colleagues in their fields.

In identifying what they would read, especially the secondary literature, the fellows usually employed a limited number of sources. Thus, four fellows regularly, if not intensively, used one or two serially issued listings of secondary sources. The four who used formal bibliography intensively also concentrated on one or two sources that they returned to repeatedly. 
"Except perhaps for one fellow who apparently read at an extraordinarily rapid rate, all seemed sensitive to the fact that they had limited time to cover a virtually unlimited array of potentially relevant literature."

And most of the fellows who did not use formal bibliography scanned a particular set of journals to keep up-to-date. In no case did we find a scholar who systematically covered a number of formal bibliographies. Survey research has also found limited use of formal bibliography. ${ }^{15}$ Except perhaps for one fellow who apparently read at an extraordinarily rapid rate, all seemed sensitive to the fact that they had limited time to cover a virtually unlimited array of potentially relevant literature. Even if they systematically searched many bibliographies, they would have time to follow up on only a few of the leads they unearthed. Because each fellow had achieved success by using a limited set of sources to identify publications to read, none had reason to develop more comprehensive patterns of information seeking.

\section{GEOGRAPHIC AND GENEALOGICAL APPROACHES TO INFORMATION}

In addition to use of formal bibliography and librarians, the fellows employed two other approaches to information that, as far as we know, have not been identified earlier in the library and information science literature. These two approaches might be called the geographic and the genealogical. Both approaches can be better understood if we remember that the humanities study the creative activities of men and women. Evidence of these activities remains either at the scene or in a collection elsewhere, usually not too far from the scene. Thus, fellows who were studying the history or people of a locality usually went to that place to find evidence. When the place studied was small, the local government archive or library was the repository consulted. For a larger region, the scholar usually found the relevant sources in its political capital or in its leading universities' libraries. The scholars in the seminar who were working on topics that had a geographic focus all went to the site of their topic and worked in the local, regional, or national repositories. Usually, the searching they did beforehand consisted of looking at a map or a telephone book to obtain the repositories' addresses; if available, a published guide to the collection might be consulted. Once at the site, the scholars relied, as we have said, on the curators and local finding aids. This process brought them to relevant primary sources.

Since all of the topics our scholars investigated involved people, much of the information seeking entailed tracking documents about individuals, or what we call the genealogical approach. In one case, for political reasons, the papers of the relevant people were still in private hands. The scholar used the telephone book of the locality where the descendants of many of these subjects lived to find current owners of relevant papers. Another scholar used information about the provenance of a collection to identify descendants of his subjects. Through these he located descendants, he located more sources. Several scholars used interviews as sources. The names of the interviewees were traced in a variety of ways, especially through their friends and colleagues, who were often informants themselves, as well as through phone books or through contacts in the locale under study. The scholar would also search the finding aids of a special collection for the names of these people and then examine the documents and artifacts so identified.

To a smaller degree, the fellows applied the geographic approach to secondary sources. Key journals that they read focused on the places they were studying. Thus, journals published by local, regional, or national historical, literary, or folklore societies are very important. The fellows relied, too, on advertisements of book dealers from their places of interest to learn about the latest monographic literature. Such sources were particularly important for scholars working abroad. Fi- 
nally, some found bibliographies that are arranged geographically very helpful.

\section{IMPLICATIONS FOR FUTURE RESEARCH AND DESIGN OF LIBRARY SERVICES}

Many of the findings of this study either corroborate previous research or do not contradict what has been established. Therefore it is likely that future investigations will find similar patterns of information seeking among humanists. At the same time, this article is based on conversations with only eleven humanists who publish more than most academics. It will be important to test on larger populations the findings of this study that break new ground. For example, will survey research confirm that humanists consult special collections librarians, including archivists, but almost never talk with reference librarians? Do humanists ignore reference librarians because of a reluctance to reveal a lack of knowledge about common library materials and systems or because they do not trust generalist librarians? Will the rapid rise in the use of computers by humanists and the development of databases and software lead to increased use of machine-readable bibliography and information by humanists? How widespread are use of the geographic and genealogical approaches to information? Do some disciplines within the humanities use these two approaches, while other disciplines do not? Given that humanists usually concentrate on one or two bibliographic sources, can we generalize that, similarly, their reading of secondary sources is also focused on a small number of journals and on the books of a limited group of publishers?

While it may seem premature to suggest practical applications based on a study that raises so many questions, we suggest at least two implications for library services. First, because humanists have welldeveloped habits for finding information in their specializations, they have little need for current awareness services that inform them of the latest literature in their areas of expertise. While they are not adept at finding information on unfamiliar topics, they can locate on their own as much and sometimes more than they need to know in their areas of concentration. Second, the humanists we studied had missed the opportunity to obtain valuable assistance from reference librarians. In particular, they could have used help from reference librarians, because they are unable and lack inclination to use machine-readable bibliographic databases. Their use of computers is so limited that they have not developed the habit, as have many scholars in other fields, of readily learning new computer applications. Furthermore, the fellows, like many other humanists, generally avoid complex bibliographic sources. Consequently, they are not ready to take advantage of the great power of computerized bibliography. For example, they are not taking advantage of such assistance as the verification of inaccurate or incomplete citations, the location of copies of needed sources, and the generation of bibliography on a unfamiliar subject. Reference librarians have the skill to manipulate machinereadable sources and the knowledge of databases to choose the best ones to search. By delegating tasks like those enumerated, humanists would not waste time tediously searching through printed sources; they would be free to devote their time to other aspects of scholarship.

The reference service described here is available in virtually all academic libraries. The problem is that humanists do not seem to use it. Because humanists have little experience relying on reference, initially reference librarians will have to prove their worth by volunteering and demonstrating their services' utility. A successful demonstration will help accustom humanists to use reference services that will save them time and free them to work on the aspects of their scholarship that they alone can do. Assigning one specific librarian to a particular group of scholars might help build interpersonal ties that will foster continued use of service. Cost of such services, may, of course, be a serious problem.

Whether humanists will use reference services that are specially promoted to them and whether libraries can afford to subsidize such services are questions for 
further research. So, too, it will be important to monitor changes over time in how humanists use computers so we can determine if services recommended here are still needed. Much remains to be learned about how humanists seek and use information. As librarians learn more, they will be better able to design library programs that contribute to the humanities.

\section{REFERENCES AND NOTES}

1. Cynthia Corkill and Margaret Mann, Information Needs in the Humanities: Two Postal Surveys, CRUS Occasional Paper no.2., British Library Research and Development Department report, no.5455 (Sheffield, Eng.: Centre for Research on User Studies, Univ. of Sheffield, 1978); Margaret F. Stieg, "The Information Needs of Historians," College \& Research Libraries 42:549-60 (Nov. 1981); Deirdre Corcoran Stam, "The Information-Seeking Practices of Art Historians in Museums and Colleges in the United States, 1982-83" (D.L.S. diss., Columbia Univ., 1984); Susan S. Guest, "The Use of Bibliographic Tools by Humanities Faculty at the State University of New York at Albany," The Reference Librarian no.18:157-72 (Summer 1987); Elizabeth Bakewell, William O. Beeman, and Carol McMichael Reese, Object, Image, Inquiry: The Art Historian at Work, ed. Marilyn Schmitt (Santa Monica, Calif.: Getty Art History Information Program, 1988).

2. Guest, "Use of Bibliographic Tools," p.163; Stam, "Information-Seeking of Art Historians," p.189; Stieg, "Information Needs of Historians," p.554.

3. Herbert C. Morton and Anne Jamieson Price, "The ACLS Survey of Scholars: Views on Publications, Computers, Libraries," Scholarly Communication 5:7-11 (Summer 1986).

4. Sue Stone, "Humanities Scholars: Information Needs and Uses," Journal of Documentation 38:294-95 (Dec. 1982).

5. American Council of Learned Societies, A Report to the Congress of the United States on the State of the Humanities (New York: The Council, 1985), p.xi-xiii, 18, 89-90, 121-26.

6. John A. Centra, "Research Productivity and Teaching Effectiveness," Research in Higher Education 18:381-83 (1983).

7. Publication here is the equivalent of an article, and we use the term publication because the figures for the fellows are based on other types of publications besides journal articles. The following equivalences were used: one book equals seven articles; an edited book equals one article; a chapter in a book equals one article; and an exhibition catalog equals one article; an encyclopedia article equals .33 of an article. Book reviews and translations receive no credit. Counts were based on the fellows' curriculum vitae, submitted at the time of application to the seminar (early 1987). Publications dated $1982-86$ were counted.

8. Morton Hunt, Profiles of Social Research: The Scientific Study of Human Interactions (New York: Russell Sage Foundation, 1985), p.60-69, 111-13, 160-61, 172-73; Bruno Latour and Steve Woolgar, Laboratory Life: The Social Construction of Scientific Facts (Beverly Hills, Calif.: Sage 1979), p.45, 69.

9. Morton and Price, "ACLS Survey," p.7-13.

10. Hunt, Profiles of Social Research, p.63-9, 215-16, 280; Nigel Hawkes, The Computer Revolution (New York: Dutton, 1972), p.65-80.

11. Mary Ellen Soper, "Characteristics and Use of Personal Collection," Library Quarterly 46:412 (Oct. 1976); Paul Metz, The Landscape of Literatures: Use of Subject Collections in a University Library, ACRL Publications in Librarianship no.43 (Chicago: American Library Assn., 1983), p.13; Corkill and Mann, Information Needs in the Humanities, p.95, 98.

12. Stam, "Information-Seeking of Art Historians," 134-35; John Chapman, "Views of a History Information Officer," Humanities Information Research: Proceedings of a Seminar, CRUS Occasional Paper no.4, British Library Research and Development Department, report no.5588 (Sheffield, Eng.: Centre for Research in User Studies, Univ. of Sheffield, 1980), p.32; Carole Smith, "Problems of Information Studies in History" in Humanities Information, p. 29-30.

13. Sue Stone, "CRUS Humanities Research Programme," in Humanities Information Research, p.15-16; Stam, "Information-Seeking of Art Historians," 121-22.

14. Stam, "Information-Seeking of Art Historians," p.121-22.

15. Corkill and Mann, "Information Needs in the Humanities," p.84. 